Article

\title{
Evaluation of Energy Consumption in the Mercury Treatment of Phosphor Powder from Spent Fluorescent Lamps Using a Thermal Process
}

\author{
Yong Choi and Seung-Whee Rhee * \\ Department of Environmental Engineering, College of Engineering, Kyonggi University, 154-42, \\ Gwanggyosan-ro, Yeongtong-gu, Gyeonggi-do 16227, Korea; oskn1105@kyonggi.ac.kr \\ * Correspondence: swrhee@kyonggi.ac.kr; Tel.: +82-31-249-9736
}

Received: 31 August 2017; Accepted: 24 October 2017; Published: 3 November 2017

\begin{abstract}
In a pilot-plant-scale thermal mercury treatment of phosphor powder from spent fluorescent lamps, energy consumption was estimated to control mercury content by the consideration of reaction kinetics. Mercury content was analyzed as a function of treatment temperature and time. The initial mercury content of the phosphor powder used in the thermal process was approximately $3500 \mathrm{mg} / \mathrm{kg}$. The target mercury content in the phosphor powder thermal process of the phosphor powder was $5 \mathrm{mg} / \mathrm{kg}$ or less at $400{ }^{\circ} \mathrm{C}$ or higher because the target mercury content was recommended by Minamata Convention and Basel Convention. During thermal processing, the reaction rate was represented by a first order reaction with the Arrhenius equation. The reaction rate constant increased with temperature from $0.0112 \mathrm{~min}^{-1}$ at $350{ }^{\circ} \mathrm{C}$ to $0.0558 \mathrm{~min}^{-1}$ at $600{ }^{\circ} \mathrm{C}$. The frequency factor was $2.51 \mathrm{~min}^{-1}$, and the activation energy was $6509.11 \mathrm{kcal} / \mathrm{kg}$. Reaction rate constants were used to evaluate the treatment time required to reduce mercury content in phosphor powder to be less than $5 \mathrm{mg} / \mathrm{kg}$. The total energy consumption in a pilot-plant-scale thermal process was evaluated to determine the optimal temperature for removing mercury in phosphor powder.
\end{abstract}

Keywords: phosphor powder; thermal process; energy consumption; mercury treatment

\section{Introduction}

Mercury and its compounds have become the focus of international concern because of the Minamata Convention. Recycling studies on spent fluorescent lamps containing mercury are being conducted in several countries [1]. Technologies used to recycle spent fluorescent lamps are recognized as core technologies for treating mercury and can be generally categorized into dry and wet recycling technologies [2]. Internationally, dry technology is preferred for treating mercury because wastewater is not generated and valuable materials are easily recovered. Dry technology used in Sweden's Mercury Recovery Technology (MRT) system and Germany's Herborn system has been modified and implemented in Korea (Republic of) [3-5]. Massacci et al. reported on treatment methods of mercury-contaminated material and the technology combined with screening, attrition, and thermal treatment on a Monte Amiata area in Tuscany, Italy [6]. In order to remove mercury in solid materials, the thermal decomposition technology had developed and used by Pittsburgh Mineral and Environmental Technology Corporation, USA [7].

In Korea, spent fluorescent lamps are managed by the Extended Producer Responsibility (EPR) System under the Act on the promotion of saving and recycling of resources. According to the Korea Environment Corporation (KECO), in 2014, about seven thousand tons of spent fluorescent lamps were recycled at a rate of approximately $35 \%$ and most spent fluorescent lamps had not been collected [8]. It is estimated that most spent fluorescent lamps are disposed by incineration or in landfills, and some may be left without undergoing appropriate treatment. Rhee et al. (2013) found 
that most mercury in spent fluorescent lamps is contained in phosphor powder, so they need to be treated appropriately [9-11]. Choi et al. reported mercury content in phosphor powder of spent linear fluorescent lamps was about $3500 \mathrm{mg} / \mathrm{kg}$ or higher [12].

Phosphor powder also contains rare earth metals, e.g., yttrium and europium [13,14]. Rare earth metals are mainly present in the earth's crust and are concentrated in some countries such as China. Internationally, research on the recovery of rare earth metal from various sources, including e-wastes are conducted for securing them [15-18]. Accordingly, phosphor powder after treating mercury can be used as a raw material in the rare earth metal industry, the cement industry, and the ceramic industry.

For mercury treatment, it can be volatilized by thermal processes and collected by cooling systems in dry technology. To utilize thermal processes in mercury treatment from phosphor powder, the treatment should be conducted at temperatures higher than $356.6^{\circ} \mathrm{C}$, the boiling point of elemental mercury. Raposo et al. studied various types of mercury contained in spent fluorescent lamps; some types can be easily oxidized, so thermal processes conducted at temperatures higher than $400{ }^{\circ} \mathrm{C}$ should be considered [19]. The United States Environmental Protection Agency (US EPA) provides information for treating mercury in soil, waste, and water; of these, thermal treatments include a rotary kiln and an indirectly heated screw. The typical treatment temperature for mercury removal is reported as being between 320 and $700{ }^{\circ} \mathrm{C}$ [20]. In the thermal process for phosphor powder, mercury vapor, which is not recovered through the cooling system, can be controlled by an adsorption process using a special activated carbon.

In this study, the reaction kinetics for mercury removed from phosphor powder using a pilot-plant-scale thermal process was estimated. The reaction rate constants were estimated with changing temperature and treatment time as experimental variables. The treatment time for phosphor powder was calculated using the reaction rate constant and the activation energy. The mercury content of the phosphor powders recovered through the thermal process was measured using the gold amalgam method and atomic absorption spectrophotometry using a DMA (direct mercury analyzer), described in the US EPA 7473 methods [21]. Finally, energy consumption was evaluated by the reaction kinetics in the optimal conditions of the thermal process for controlling mercury in phosphor powder.

\section{Theoretical Background}

Concentration changes with time can be represented using the reaction rate equation. The integrated rate equation can estimate a reduced concentration after a certain reaction time using reaction rate equations in a specific order [22]. The time to reach at the target mercury content was estimated by the reaction rate constant and an initial mercury content. In this study, the thermal processing for controlling mercury was assumed to be the 1st order reaction, and the reaction rate can be determined as follows:

$$
\begin{gathered}
\frac{d C}{d t}=-k C \\
\frac{d C}{C}=-k d t \\
\int_{C_{0}}^{C} \frac{d C}{C}=-k \int_{0}^{t} d t \\
\ln C=\ln C_{0}-k t
\end{gathered}
$$

where $C_{0}$ is the initial mercury content, $C$ is the mercury content after a certain reaction time, and $k$ is the reaction rate constant. The reaction rate constant is expressed in Equation (5) according to the Arrhenius equation [22].

$$
k=A \exp \left(-\frac{E_{a}}{R T}\right)
$$

where $A$ is the frequency factor, $E_{a}$ is the activation energy, $R$ is the universal gas constant, and $T$ is the absolute temperature. When the natural logarithm is considered in Equation (5), it can be expressed 
as Equation (6). Temperature and the reaction rate constant can be plotted, the activation energy is determined by the slope, and frequency factor is determined by the intercept.

$$
\ln k=\ln A-\frac{E_{a}}{R T} .
$$

The total energy usage for the pilot-plant-scale thermal process was expressed by Equation (7). Total energy consumption included heat-up, the maintaining time for temperature, heat loss, and basic power to drive the apparatus.

$$
Q_{\text {Total }}=Q_{\text {Heat-up }}+Q_{\text {Loss of Heat-up }}+Q_{\text {Maintaining }}+Q_{\text {Loss of Maintaining }}+Q_{\text {Basic power }} .
$$

The energy source of the pilot-plant-scale thermal process was used via electricity. During the main power supply for heat-up and device operation, the electricity was continuously consumed. Therefore, the use of $Q_{\text {Heat-up }}(\mathrm{kWh})$ and $Q_{\text {Basic power }}(\mathrm{kWh})$ can be expressed in Equation (8) according to Joule's law [23].

$$
Q_{\text {Heat-up and Basic power }}=I^{2} R t
$$

where $I$ is the electric current, $R$ is the resistance, and $t$ is the operation time.

In order to estimate $Q_{\text {maintaining }}$ in Equation (7), the total calories required to maintain the temperature in the thermal process were obtained with Equation (9). Total calories need to be converted to power consumption $(\mathrm{kW})$, reflecting the treatment time of phosphor powder calculated from the reaction rate constant. The thermal mercury treatment process for phosphor powder was designed as $8 \mathrm{~h}$ per day on the basic specifications. Thus, the energy consumption required to maintain the temperature in the thermal process can be obtained by consideration of the ratio of operation time to basic specification time (8 h) as shown in Equation (9).

$$
Q_{\text {maintaining }}=m C p\left(T-T_{0}\right) \frac{t}{t_{0}}
$$

where $m(\mathrm{~g})$ is the weight of the heating object, $C p(\mathrm{~J} / \mathrm{gK})$ is the specific heat, $\left(T-T_{0}\right)$ is the temperature difference between the treatment process and the outside air, $t$ is the operation time of recycling process, and $t_{0}$ is the basic specification time that was designed as a recycling apparatus.

Heat loss from heat-up and from maintaining the temperature of the apparatus can be expressed in Equation (10).

$$
Q_{\text {Loss of Heat-up and Loss of Maintaining }}=L t
$$

where $L(\mathrm{~kW})$ is the convection heat loss from the outside air and $t(\mathrm{~h})$ is the operation time. $L$ is expressed in Equation (11).

$$
L=h A\left(T-T_{0}\right)
$$

where $h\left(\mathrm{~W} / \mathrm{m}^{2} \mathrm{~K}\right)$ is the heat transfer coefficient, $A\left(\mathrm{~m}^{2}\right)$ is the surface area of the heating drum that is heated to treat the mercury in the phosphor powder [24].

The heat transfer coefficient $(h)$ can be expressed by Equation (12) using the Nusselt number.

$$
h=N u \frac{k}{D}
$$

where $N u$ (dimensionless) is the Nusselt number, $k(\mathrm{~W} / \mathrm{mK})$ is the thermal conductivity, and $D$ is the diameter of the heating drum. The definition of $N u$ can be expressed in Equation (13) by the relation of the Prandtl number and the Grashof number. They are dimensionless numbers under the condition of the heating drum placed in the air.

$$
N u=0.53(P r \cdot G r)^{1 / 4} \text { at } 10^{4}<\operatorname{Pr} \cdot G r<10^{9} .
$$


The Prandlt number (Pr) and the Grashof number (Gr) can be expressed in Equations (14) and (15), respectively. Each number is calculated by taking the physical properties of the air, according to the temperature of the heating drum.

$$
\begin{gathered}
\operatorname{Pr}=\frac{v}{\alpha} \\
G r=\frac{g \beta\left(T-T_{0}\right) D^{3}}{v^{2}} .
\end{gathered}
$$

In Equation (14), $v$ is the dynamic viscosity of air, and $\alpha$ is the thermal diffusivity. In Equation (15), $g$ is the gravitational acceleration, $\beta$ is the cubical expansion coefficient, and $D$ is the diameter of cylinder [24].

In $Q_{\text {Loss of Heat-up }}, h$ is calculated using the average temperature since the temperature changes with heat-up. In $Q_{\text {Loss of Maintaining, }} h$ is calculated from the maintaining temperature. Additionally, in the calculation of $L, A$ took the surface area of all sides of the heating drum.

\section{Material and Methods}

\subsection{Materials}

Phosphor powder used in the thermal mercury treatment process was recovered from a recycling facility of spent linear fluorescent lamps. In the recycling facility, phosphor powder was recovered using screen separation after spent fluorescent lamps were shredded. The spent linear fluorescent lamps in the recycling facility were of $32 \mathrm{~W}$. The diameter of the spent linear fluorescent lamps was $25.5 \pm 1.5 \mathrm{~mm}$ and the length was $1198.0 \pm 1.5 \mathrm{~mm}$. The weight was about $160 \mathrm{~g}$ per lamp, though there were difference by manufacturer. The amount of phosphor powder contained in the spent linear fluorescent lamps was about $2.0 \%$ [12].

\subsection{Experimental Apparatus and Method}

A schematic diagram of the pilot-plant-scale thermal mercury treatment process is shown in Figure 1. The thermal process consisted of the heating drum to vaporize mercury contained in the phosphor powder, the cooling system for condensation and recovery of vaporized mercury, and an activated carbon adsorption tower to prevent the emission of uncondensed mercury into the atmosphere.

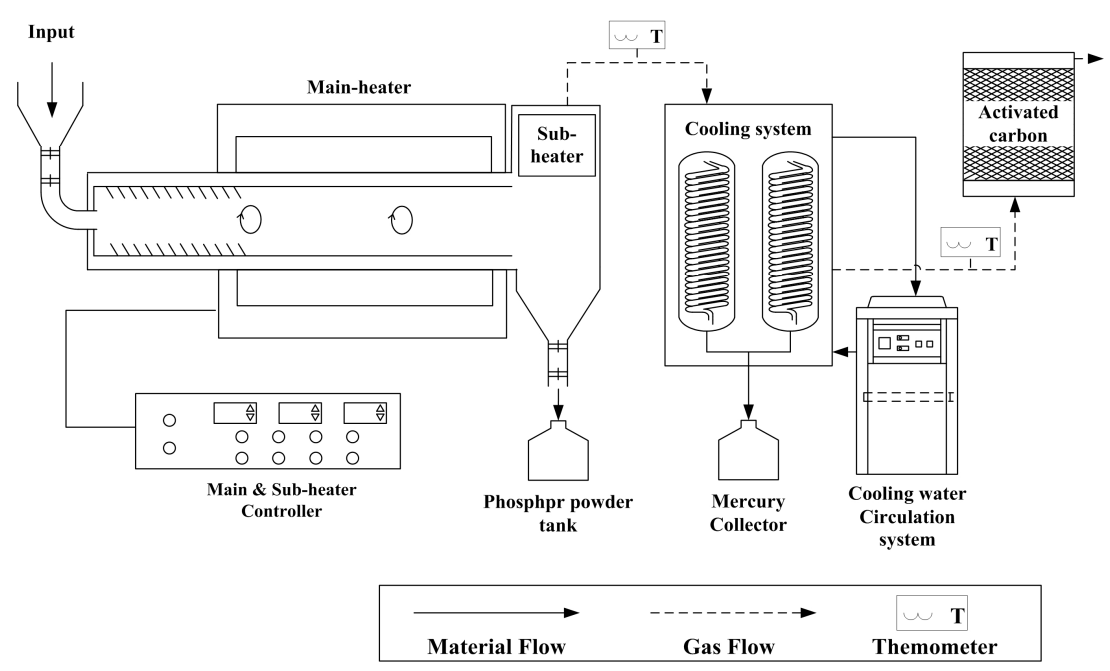

Figure 1. A schematic diagram of the thermal process for phosphor powder.

The heating drum was rotated at a speed of $2 \mathrm{rpm}$ when the phosphor powder was added, and the temperature was increased to $700{ }^{\circ} \mathrm{C}$. The inlet and outlet of the heating drum included a 
double damper to prevent heat loss due to external air inflow. A sub-heater was installed to prevent condensation when the vaporized mercury moved from the heating drum to the cooling system.

The mercury content of the phosphor powder was determined as a function of temperature and time. The quantity of phosphor powder added to the heating drum was constant for all experiments, namely, $10.0 \mathrm{~kg}$. The experimental temperatures were between 350 and $600{ }^{\circ} \mathrm{C}$, and times ranged from 60 to $480 \mathrm{~min}$. Mercury contents were measured more than 5 times at the identical condition. The mean value and the standard deviation for mercury content were obtained from 5 experimental data.

\section{Results and Discussion}

\subsection{Characteristics of Phosphor Powder}

The initial characteristics of phosphor powders prior to the pilot-plant-scale thermal process are shown in Table 1 and Figure 2. From the particle size distribution, as shown in Figure 2, the largest weight fraction was $4.02 \%$ at a particle size of $23.99 \mu \mathrm{m}$, and the particle size, which accounted for more than $80 \%$ of weight fraction, was $74.00 \mu \mathrm{m}$ in the cumulative weight fraction of the phosphor powder. The median and characteristic particle sizes in the cumulative weight distribution were $29.00 \pm 1.96 \mu \mathrm{m}$ and $38.28 \pm 2.14 \mu \mathrm{m}$, respectively. Hirajima et al. (2005) reported that the median particle size of phosphor powder present in new fluorescent lamps was $14.0 \mu \mathrm{m}$, which is smaller than that found here [25]. Phosphor powder was recovered using mechanical screen separation during recycling of spent fluorescent lamps, so the powder contained impurities, such as fine glass powder. Park et al. (2016) reported a median phosphor powder particle size of 30 60 $\mu \mathrm{m}$, similar to the median particle size measured in this study [1]. The initial mercury content of phosphor powder was $3418.34 \pm 269.26 \mathrm{mg} / \mathrm{kg}$. In Korea, wastes containing mercury has been regulated by Korea Extraction Test in which the regulatory concentration for mercury was $2.0 \mathrm{ppb}$ in the extracted solution, but the standard level on mercury in solid phase is not regulated under Waste Management Act. The Minamata Convention and Basel Convention recommended a mercury content of $5.0 \mathrm{mg} / \mathrm{kg}$ for the legal standard [26]. Therefore, phosphor powder containing mercury at high concentrations should undergo appropriate treatment.

Table 1. Characteristics of initial phosphor powder.

\begin{tabular}{cc}
\hline Type & Phosphor Powder \\
\hline Median particle size $(\mu \mathrm{m})$ & $29.00 \pm 1.96$ \\
Characteristic particle size $(\mu \mathrm{m})$ & $38.28 \pm 2.14$ \\
Mercury content $(\mathrm{mg} / \mathrm{kg})^{1}$ & $3418.34 \pm 269.26$ \\
\hline
\end{tabular}

${ }^{1}$ Mercury was analyzed with a DMA (direct mercury analyzer).

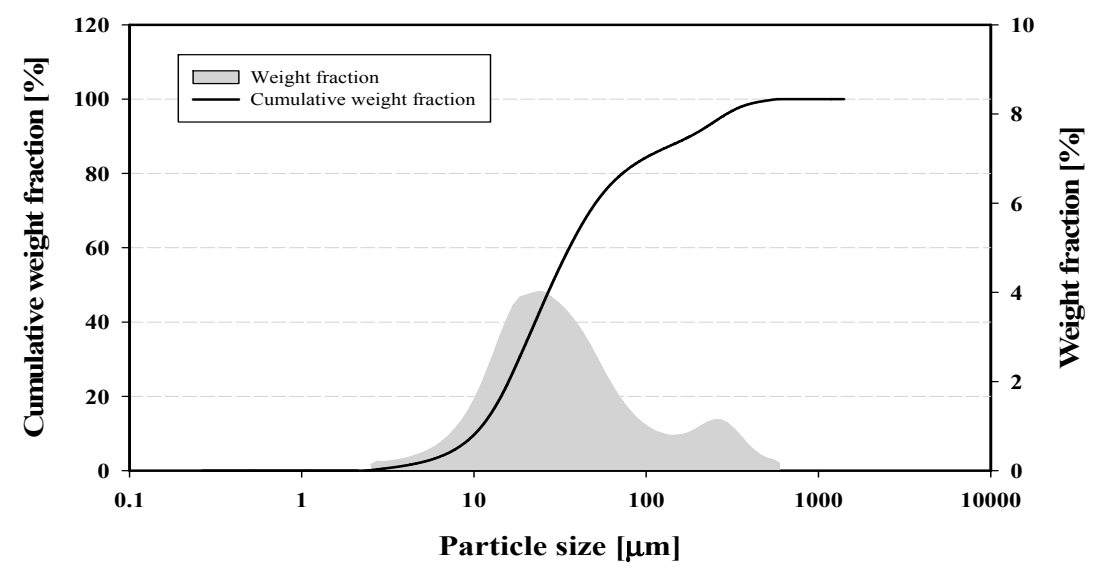

Figure 2. Particle size distribution of phosphor powder. 


\subsection{Mercury Content Variations with Temperature and Time}

The mercury content of the thermally processed phosphor powders for different temperatures and times are shown in Figure 3. At $350{ }^{\circ} \mathrm{C}$, mercury content decreased from $1019.74 \mathrm{mg} / \mathrm{kg}$ at $60 \mathrm{~min}$ to $40.90 \mathrm{mg} / \mathrm{kg}$ at $480 \mathrm{~min}$ but exceeded the recommended value of $5.00 \mathrm{mg} / \mathrm{kg}$ of the Basel Convention. At $400{ }^{\circ} \mathrm{C}$, the mercury content decreased sharply from the initial value to $16.15 \mathrm{mg} / \mathrm{kg}$ at $240 \mathrm{~min}$, and then gradually decreased to $3.24 \mathrm{mg} / \mathrm{kg}$ at $360 \mathrm{~min}$.

Busto et al. found that mercury concentrations decreased below the TCLP regulatory level at temperatures higher than $400{ }^{\circ} \mathrm{C}$ in the treatment of mercury-containing sludge, and, at $800{ }^{\circ} \mathrm{C}$, about $99.9 \%$ of mercury was removed within $1 \mathrm{~h}$ [27]. Chang et al. controlled the mercury concentrations in phosphor powder to about $98 \%$ at $450{ }^{\circ} \mathrm{C}$ [28].

The mercury content of the phosphor powder decreased sharply as temperature and time increased, and $99.9 \%$ of the mercury concentration was controlled by the thermal process. Since this was achieved within $360 \mathrm{~min}$ at $400{ }^{\circ} \mathrm{C}$ and $120 \mathrm{~min}$ at $600{ }^{\circ} \mathrm{C}$, the time decreased as treatment temperature increased. Thus, it is appropriate to thermally treat phosphor powder at $400{ }^{\circ} \mathrm{C}$ or higher for safe mercury removal.

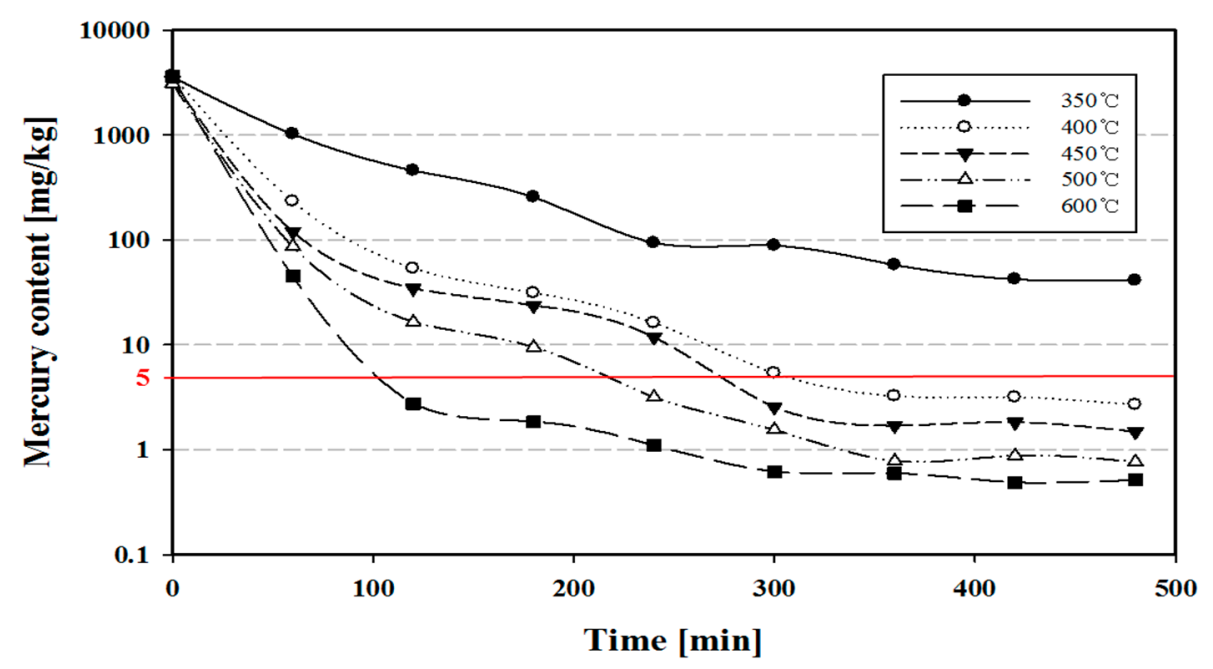

Figure 3. Mercury content of phosphor powder with temperature and time.

\subsection{Reaction Rate in a Pilot-Plant-Scale Thermal Process}

To estimate the reaction rate in a pilot-plant-scale thermal processing, the relationship between mercury concentration and time was used to determine the reaction rate equation. Variations in mercury concentrations with temperature and time can be expressed as the 1st order reaction using Equation (4). According to the results in Figure 3, the reaction rate constant can be obtained from the slope using linearization with time and $\ln (C)$. The plot showing the 1 st order reaction with respect to temperature is shown in Figure 4 . The reaction rate constants were decided to be $1.87 \times 10^{-4} \mathrm{~s}^{-1}$ at $350{ }^{\circ} \mathrm{C}$ and $9.30 \times 10^{-4} \mathrm{~s}^{-1}$ at $600{ }^{\circ} \mathrm{C}$. It was found that the reaction rate constant increased as temperature increased. The frequency factor and activation energy can be obtained by Equation (6), as shown in Figure 5. The frequency factor and activation energy in Equation (6) were estimated to be $0.042 \mathrm{~s}^{-1}$ and $6509.11 \mathrm{kcal} / \mathrm{kmol}$, respectively, as shown in Table 2.

Various research projects on reaction rates for mercury containing waste have been conducted using thermal processes. Back et al. investigated the reaction rate with temperature, treating mercury-containing sludge using lab-scale thermal processing. They found that the 1st order reaction rate constants increased from $2.4 \times 10^{-3} \mathrm{~s}^{-1}$ at $450{ }^{\circ} \mathrm{C}$ to $5.2 \times 10^{-3} \mathrm{~s}^{-1}$ at $750{ }^{\circ} \mathrm{C}$, which are higher than those in this study. A lower reaction rate constant was obtained in this study because of the difference between the lab-scale and the pilot-plant-scale and material properties used in the experiments [29]. 


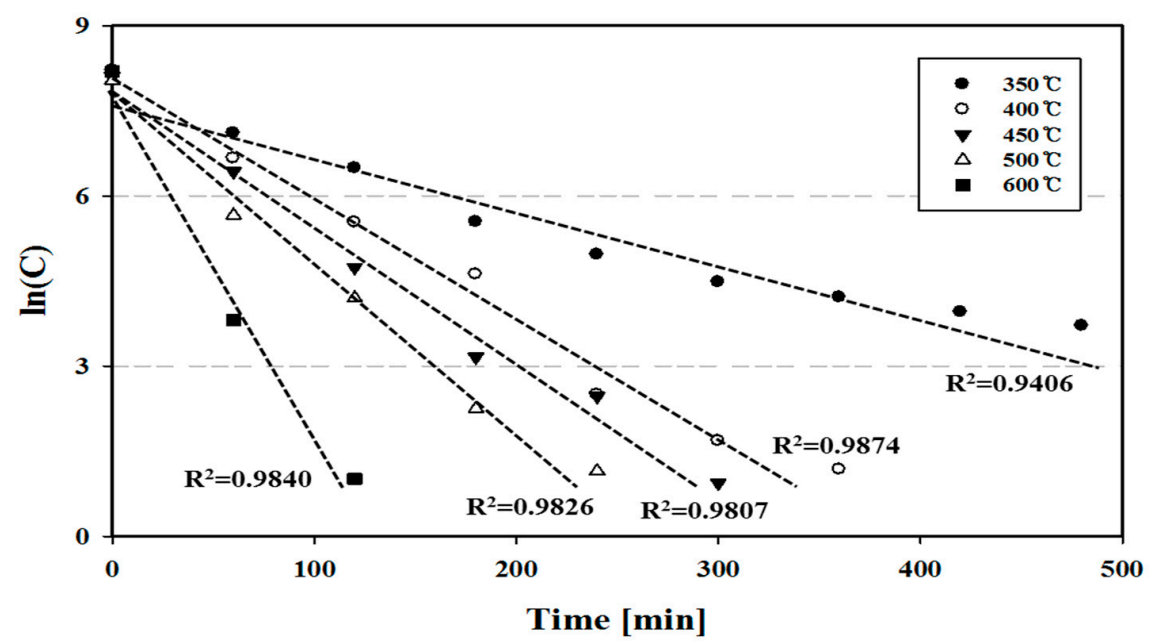

Figure 4. Reaction rate constant of the thermal process with temperature.

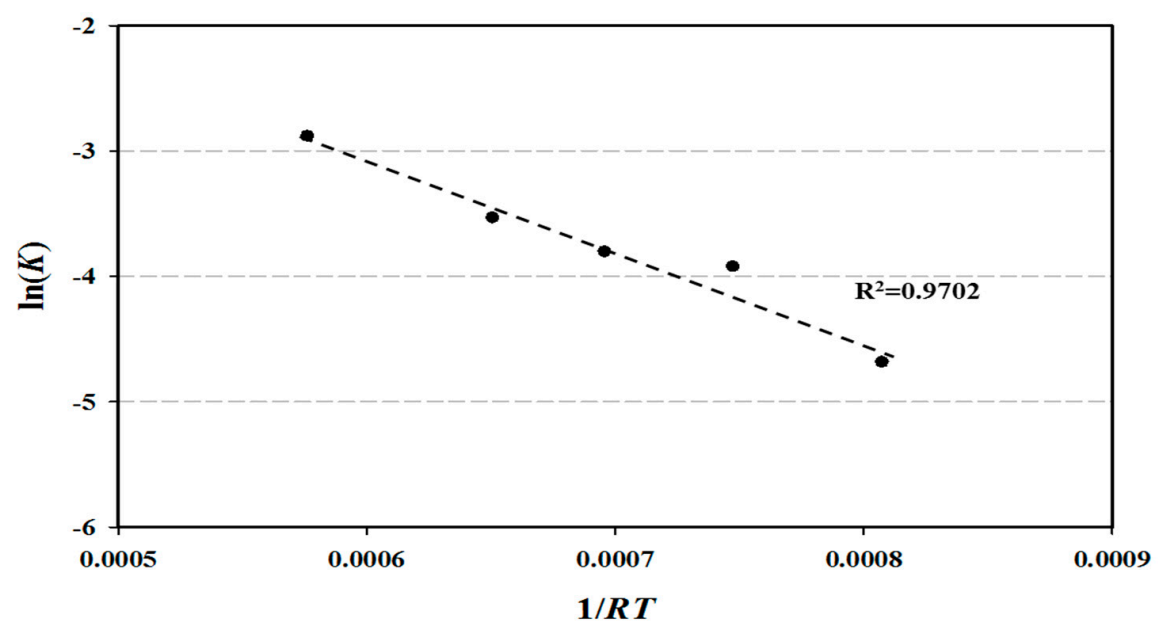

Figure 5. Plot of $\ln (K)$ versus $1 / R T$ for frequency factor and activation energy.

Table 2. Reaction rate constant and parameters on the thermal process of the phosphor powder.

\begin{tabular}{cccc}
\hline Temperature $\left({ }^{\circ} \mathbf{C}\right)$ & Reaction Rate Constant $\left(\mathbf{s}^{-\mathbf{1}}\right)$ & Frequency Factor $\left(\mathbf{s}^{-\mathbf{1}}\right)$ & Activation Energy $(\mathbf{k c a l} / \mathbf{k m o l})$ \\
\hline 350 & $1.87 \times 10^{-4}$ & & \\
400 & $3.28 \times 10^{-4}$ & & \\
450 & $3.70 \times 10^{-4}$ & 0.042 & \\
500 & $4.85 \times 10^{-4}$ & & \\
600 & $9.30 \times 10^{-4}$ & & \\
\hline
\end{tabular}

\subsection{Energy Consumption in a Pilot-Plant-Scale Thermal Process}

The power consumption of the main heater and sub heater was $18 \mathrm{~kW}$ and the basic power required to drive the process was $2 \mathrm{~kW}$. The total energy consumption of the thermal process, including energy consumption by operation time, was estimated with Equations (7)-(15).

The operating time for the thermal process consisted of heat-up time and maintaining time as factors for evaluating energy consumption in Table 3. The time required to increase the temperature of the heating drum and to maintain the temperature in the thermal process can be estimated using the reaction rate constant described in Section 4.3. The heat-up time increased as temperature increased, from $0.33 \mathrm{~h}$ at $350{ }^{\circ} \mathrm{C}$ to $1.33 \mathrm{~h}$ at $600{ }^{\circ} \mathrm{C}$, because it took more time to reach a higher temperature. The maintaining time decreased exponentially as temperature increased, from $9.79 \mathrm{~h}$ at $350{ }^{\circ} \mathrm{C}$ to 
$1.96 \mathrm{~h}$ at $600{ }^{\circ} \mathrm{C}$. This was the reason why the operating time to remove mercury sharply decreased as the operating temperature increased. Therefore, the total operation time decreased as the operating temperature increased, as shown in Table 3.

Table 3. The operation time in the thermal process with temperature.

\begin{tabular}{cccc}
\hline Temperature $\left({ }^{\circ} \mathbf{C}\right)$ & Heat-Up Time (h) & Maintaining Time (h) & Operation Time (h) \\
\hline 350 & 0.33 & 9.79 & 10.12 \\
400 & 0.50 & 5.58 & 6.08 \\
450 & 0.67 & 4.88 & 5.55 \\
500 & 1.00 & 3.68 & 4.68 \\
600 & 1.33 & 1.96 & 3.29 \\
\hline
\end{tabular}

The estimated energy consumption during the heat-up period increased continuously, from $6.33 \mathrm{kWh}$ at $350{ }^{\circ} \mathrm{C}$ to $26.60 \mathrm{kWh}$ at $600{ }^{\circ} \mathrm{C}$. Energy consumption during the constant temperature period was estimated from Equation (9) based on the heating drum material, the air in the heating drum, the amount of phosphor powder, and the conditions required to remove mercury using evaporation. The estimate energy consumption during the maintaining time was decreased from $21.28 \mathrm{kWh}$ at $350{ }^{\circ} \mathrm{C}$ to $6.83 \mathrm{kWh}$ at $600{ }^{\circ} \mathrm{C}$. For the estimation of energy consumption, heat loss due to the temperature difference between the heating drum and the outside air was taken into account using Equations (10)-(15). The energy consumption of the basic power decreased to $20.25 \mathrm{kWh}$ at $350{ }^{\circ} \mathrm{C}$ and $6.59 \mathrm{kWh}$ at $600{ }^{\circ} \mathrm{C}$, respectively. Owing to the influence of a shorter operating time at higher temperatures, basic power decreased as temperature increased.

The total energy consumption for the thermal process is presented in Figure 6. The total energy consumption for the thermal process was highest at $350{ }^{\circ} \mathrm{C}, 47.86 \mathrm{kWh}$, and lowest at $400{ }^{\circ} \mathrm{C}, 35.37 \mathrm{kWh}$. Total energy consumption increased to $39.92 \mathrm{kWh}$ at $500{ }^{\circ} \mathrm{C}$ and converged to a certain level at temperatures $500{ }^{\circ} \mathrm{C}$ or higher. Therefore, the optimal temperature for treating mercury of phosphor powder in the pilot-plant-scale thermal process was $400^{\circ} \mathrm{C}$, which consumed the lowest amount of energy.

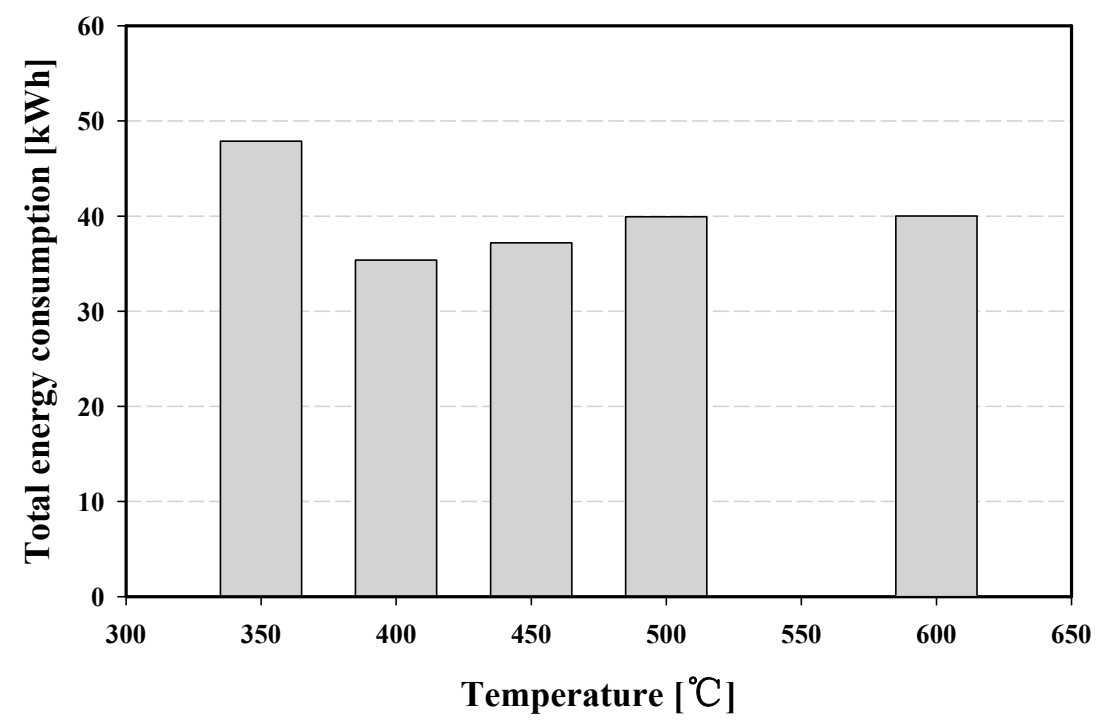

Figure 6. Total energy consumption of the thermal process with temperature.

\section{Conclusions}

The mercury content of phosphor powder from spent fluorescent lamps was measured as the function of temperature and time in the pilot-plant-scale thermal experiment. In addition, reaction rates 
were estimated based on mercury content and time, and the optimal conditions for the pilot-plant-scale thermal process based on energy consumption were evaluated. The primary conclusions were as follows:

1. From the characteristics of phosphor powder, the median particle size was $29.00 \pm 1.96 \mu \mathrm{m}$, and the characteristic particle size was $38.28 \pm 2.14 \mu \mathrm{m}$.

2. The initial mercury content in phosphor powder was very high, $3418.34 \pm 269.26 \mathrm{mg} / \mathrm{kg}$. In the thermal process, mercury content decreased to less than $5.00 \mathrm{mg} / \mathrm{kg}$ at $400{ }^{\circ} \mathrm{C}$ or higher.

3. The required treatment time for controlling mercury in phosphor powder was estimated from the 1 st reaction equation, and it decreased exponentially from $9.79 \mathrm{~h}$ at $350^{\circ} \mathrm{C}$ to $1.96 \mathrm{~h}$ at $600{ }^{\circ} \mathrm{C}$. At $400{ }^{\circ} \mathrm{C}$, the operating time in the thermal process for safe mercury treatment was determined to be $360 \mathrm{~min}$.

4. The reaction rate constant increased as temperature increased from $1.87 \times 10^{-4} \mathrm{~s}^{-1}$ at $350{ }^{\circ} \mathrm{C}$ to $9.30 \times 10^{-4} \mathrm{~s}^{-1}$ at $600{ }^{\circ} \mathrm{C}$. The frequency factor was $0.042 \mathrm{~s}^{-1}$, and the activation energy was $6509.11 \mathrm{kcal} / \mathrm{kmol}$ in the $1 \mathrm{st}$ order reaction.

5. The total energy consumption of the pilot-plant-scale thermal process was the lowest at $400{ }^{\circ} \mathrm{C}$ at $35.37 \mathrm{kWh}$. Hence, the optimum conditions for treating phosphor powder was $400{ }^{\circ} \mathrm{C}$ in temperature and $360 \mathrm{~min}$ in operation time.

Acknowledgments: This work was supported by Kyonggi University's Graduate Research Assistantship 2017.

Author Contributions: All authors significantly contributed the article. Yong Choi mainly conducted experiments and analysis. Seung-Whee Rhee organized the overall works including discussion and writing the article.

Conflicts of Interest: The authors declare no conflict of interest.

\section{References}

1. Park, H.S.; Rhee, S.W. Estimation of retorted phosphor powder from spent fluorescent lamps by thermal process. Waste Manag. 2016, 50, 257-263. [CrossRef] [PubMed]

2. Rhee, S.W. Control of mercury emissions: Policies, technologies, and future trends. Energy Emiss. Control Technol. 2015, 4, 1-15. [CrossRef]

3. Rhee, S.W.; Park, H.S.; Yoo, H.S. Efficient Management System for Mercury-containing Waste according to the Current Status of Spent Fluorescent Lamps. J. Environ. Policy 2015, 14, 135-158. [CrossRef]

4. Herborn GMBH. Lamp Recycling "System Herborn". Available online: http://www.system-herborn.de/ en/recyclingsystem-herborn/lamp-recycling-unit (accessed on 3 August 2017).

5. MRT System. Lamp Processing. Available online: http://www.mrtsystem.com/products/lamp-recycling/ (accessed on 3 August 2017).

6. Massacci, P.; Piga, L.; Ferrini, M. Technical note application of physical and thermal treatment for the removal of mercury from contaminated materials. Miner. Eng. 2000, 13, 963-967. [CrossRef]

7. Wang, J.; Feng, X.; Anderson, C.W.N.; Xing, Y.; Shang, L. Remediation of mercury contaminated sites-A review. J. Hazard. Mater. 2012, 221, 1-18. [CrossRef] [PubMed]

8. Korea Environment Corporation (KECO). Expended Producer Responsibility Enforced 13 Years (Assessment on Result of Operation); Korea Environment Corporation (KECO): Incheon, Korea, 2017.

9. Rhee, S.W.; Choi, H.H.; Park, H.S. Performance evaluation of material separation from spent fluorescent lamps using the thermal end-cutting method. J. Mater. Cycles Waste Manag. 2013, 15, 503-509. [CrossRef]

10. Rhee, S.W.; Park, H.S. Mercury distribution of major components from 3-banded and general spent fluorescent lamp. Korea Soc. Waste Manag. 2013, 30, 265-271. [CrossRef]

11. Rhee, S.W.; Park, H.S.; Choi, H.H. Comparison of mercury distribution between the types of spent fluorescent lamp. Arch. Metall. Mater. 2015, 60, 1297-1299. [CrossRef]

12. Choi, H.J.; Rhee, S.W. Material flow analysis of the recycling process for linear type spent fluorescent lamp. J. Korea Soc. Waste Manag. 2016, 33, 537-546. [CrossRef]

13. Rhee, S.W.; Choi, H.H.; Park, H.S. Characteristics of mercury emission from linear type of spent fluorescent lamp. Waste Manag. 2014, 34, 1066-1071. [CrossRef] [PubMed] 
14. Wu, Y.; Yin, X.; Zhang, Q.; Wang, W.; Mu, X. The Recycling of rare earths from waste tricolor phosphors in fluorescent lamps: A review of processes and technologies. Resour. Conserv. Recycl. 2014, 8, 21-31. [CrossRef]

15. Binnermans, K.; Jones, P.T.; Blanpain, B.; Gerven, T.V.; Yang, Y.; Walton, A.W.; Buchert, M. Recycling of Rare earths: A critical review. J. Clear Prot. 2013, 51, 1-22. [CrossRef]

16. Innocenzi, V.; Michelis, I.D.; Kopacek, B.; Veglio, F. Yttrium recovery from primary and secondary sources: A review of main hydrometallurgical processes. Waste Manag. 2014, 34, 1237-1250. [CrossRef] [PubMed]

17. Belardi, G.; Ippolito, N.; Piga, L.; Serracino, M. Investigation on the status of rare earth elements contained in the powder of spent fluorescent lamps. Thermochim. Acta 2014, 591, 22-23. [CrossRef]

18. Ippolito, N.M.; Innocenzi, V.; Michelis, I.D.; Medici, F. Rare earth elements recovery from fluorescent lamps: A new thermal pretreatment to improve the efficiency of the hydrometallurgical process. J. Clear Prot. 2017, 153, 287-298. [CrossRef]

19. Raposo, C.; Windmoller, C.C.; Durao Junior, W.A. Mercury speciation in fluorescent lamps by thermal release analysis. Waste Manag. 2003, 23, 879-886. [CrossRef]

20. United States Environmental Protection Agency (US EPA). Treatment Technologies for Mercury in Soil, Waste and Water. Section 5 Thermal Treatment; United States Environmental Protection Agency (US EPA): Washington, DC, USA, 2007.

21. United States Environmental Protection Agency (US EPA). Method 7473. Mercury in Solids and Solutions by Thermal Decomposition, Amalgamation, and Atomic Absorption Spectrophotometry. Available online: https:/ / www.epa.gov/sites/production/files/2015-12/documents/7473.pdf (accessed on 16 October 2017).

22. Michael, D.; LaGrega-Phillip, L.; Buckingham·Jeffrey, C.E. Hazardous Waste Management, 2nd ed.; Mc Graw Hill: New York, NY, USA, 2001; pp. 137-138, ISBN 0-07-039365-6.

23. Maddock, R.J.; Calcutt, D.M. Electronics for Engineers, 2nd ed.; Longman Scientific \& Technical: Harlow, Essex, UK, 1994; pp. 28-75, ISBN 0-582-21583-8.

24. Klein, S.; Nellis, G. Thermodynamics; Cambridge University Press: New York, NY, USA, 2012; pp. 92-137, ISBN 978-0-521-19570-6.

25. Hirajima, T.; Bissombolo, A.; Sasaki, K.; Nakayama, K.; Hirai, H.; Tsunekawa, M. Floatability of rare earth phosphors from waste fluorescent lamps. Int. J. Miner. Process. 2005, 77, 187-198. [CrossRef]

26. Minamata Convention on Mercury. Compilation of Additional Information on the Use of Mercury Waste Tresholds. Available online: http:/ / www.mercuryconvention.org/Portals/11/documents/meetings/COP1/ English/1_26_e_waste.pdf (accessed on 16 August 2017).

27. Busto, Y.; Cabrera, X.; Tack, F.M.G.; Verloo, M.G. Potential of thermal treatment for decontamination of mercury containing wastes from chlor-alkali industry. J. Hazard. Mater. 2011, 186, 114-118. [CrossRef] [PubMed]

28. Chang, T.C.; You, S.J.; Yu, B.S.; Chen, C.M.; Chiu, Y.C. Treating high-mercury-containing lamps using full-scale thermal desorption technology. J. Hazard. Mater. 2009, 162, 967-972. [CrossRef] [PubMed]

29. Back, S.K.; Seo, Y.C.; Sung, J.H.; Jang, H.N.; Kim, J.H.; Kim, K.H.; Kim, Y.L.; Kwon, M.H. Thermal Degradation Characteristics of Mercury in Waste Sludge Containing High Concentrated Mercury. Journal of Korea Society of Waste Management. J. Korea Soc. Waste Manag. 2014, 31, 300-306. [CrossRef]

(C) 2017 by the authors. Licensee MDPI, Basel, Switzerland. This article is an open access article distributed under the terms and conditions of the Creative Commons Attribution (CC BY) license (http://creativecommons.org/licenses/by/4.0/). 